\section{The National Day of Prayer}

His MAJesty THE KING, having expressed a desire that March 23 should be observed as a national day of prayer, statements have been issued by leaders of religious bodies in Great Britain. Dr. Lang, the Archbishop of Canterbury, after observing that "we are now approaching or entering a critical stage in the tremendous struggle", considers it most fitting that the King, as head of the nation, "should once again call it to renew the acknowledgement of its need of God and dependence on Him", and to pray for "His forgiveness of all that has been amiss in our national life, for strength and guidance in the stern and testing days which may be coming, and, if it be His will, for good success". The Primate observes also that with such prayers it is right that "we should offer thanksgivings for mercies already received", alluding to "the wonderful way'in which we have escaped the dangers which surrounded us last summer and autumn'. His Eminence Cardinal Hinsley, Archbishop of Westminster, declares that, "the stern trials that face us call for the light and strength which God alone can give. Moreover, the mercies we have received in answer to prayer should cause us to lift up our hearts in thanksgiving to 'the God of all consolation'",. His Eminence also urges the faithful "to pray that this deadly strife among nations may speedily ond in a true peace based on justice and love".

The statement issued by the Rev. Sidney M. Berry and the Rev. S. W. Hughes, on behalf of the Free Church Federal Council, appeals to Free Churchmen throughout the country to observe the Day of Prayer. "The struggle in which we are now engaged they declare, "will never issue in the kind of world we want to see by relying merely on the power of material weapons and resources. Our supreme need is for God's guidance and strength". They urge that the day of prayer be freed "from any false ideas that prayer is a kind of magic, or that we only turn to God when we are at our wit's end". To be truly observed the day must mean "a dedication of ourselves through days of peril into those other and happier days of victory and peace, when dangers of another kind may come to us". 'The Chief Rabbi, Dr. J. H. Hertz, in his statement declares that "his Majesty's Jewish subjects will loyally obey the royal summons", using "supplications to our Father in Heaven for strength and guidance, as well as prayers of thanksgiving for the mercies and victories hitherto granted to the forces of freedom".

\section{Railways under War Conditions}

THE vigorous defence of the operation of the railways under war conditions, which Lord Stamp offered in his chairman's address at the annual general meeting on March 7 of the London, Midland and Scottish Railway Company, contained an interesting reference to the work of the Company's Research Department, the very great value of which in solving war-time problems he emphasized. Such problems as substitute materials, salvage, air raid precautions and black-out could only be solved quickly and effectively by scientific methods. Lord Stamp referred particularly to the work of the Research Department on treatment of the windows of signal boxes without interfering with clear vision, which had proved so effective that in the boxes so treated not a single man had been injured by glass splinters; the importance of this in maintaining confidence and operating efficiency can be imagined. With the lighting section, the Research Department has also contributed to the development of scientific methods, enabling a combination of safety from observation with the best permissible lighting to be used in dealing with the innumerable problems of lighting the black-out in goods sheds, marshalling yards and elsewhere. Lord Stamp's spirited reply to criticism, which has some. times been somewhat irresponsible and carping, made it clear that the handicaps on the railways and the strain on their reserves could be mitigated by intelligent forethought on the part of the Service Departments. It may be hoped that his indictment of want of foresight or worse will not escape the notice of that invaluable watch-dog over administrative weaknesses - the Select Committee on National Expenditure.

\section{British Medical Students in the United States}

The Minister of Health, replying in the House of Commons to a question by Prof. A. V. Hill, said that he was aware that an offer had been received from the Rockefeller Foundation in New York to undertake and provide for the clinical training and maintenance of selected British medical students in medical schools in the United States of America and in Canada. A committee to select students has been set up in Great Britain under the chairmanship of the Vice-Chancellor of the University of Manchester, Prof. J. S. B. Stopford, and consisting of Prof. H. R. Dean (vice-chairman), Prof. H. W. B. Cairns, Mr. H. L. Eason, Prof. G. E. Gask, Mr. G. F. Gibberd, Dr. A. M. H. Gray, Prof. A. V. 'Hill, Surgeon Rear Admiral J. W. McNee, Sir Walter Moberly, Sir Franklin Sibly and Mr. W. B. Brander, of the Universities Bureau of the British Empire, c/o University College, Gower Street, London, W.C.1 (secretary). The first group of students will leave for America as soon as possible.

The Rockefeller Foundation's grant is of 100,000 dollars, and will suffice for about twenty-five studentships, providing cost of tuition and maintenance for two or three years. It comes at an opportune moment, when clinical studies in Great Britain are of necessity being continued under difficulties imposed by shortage of teaching staff, many of whom are on active service, and by damage caused to some of the leading hospitals by enemy action. The selected students will go to various universities in the United States and Canada, where they will be able not only to complete their medical studies, but also to obtain valuable experience of practice and research in North America. This generous grant is yet one more demonstration of the desire to help and practical interest of the United States in the preservation of European standards of life. 